\title{
Um discurso sobre o nada: a depreciação à retórica em "O
}

\author{
Alienista" \\ A discourse on nothingness: the depreciation to rhetoric in "The \\ Alienist"
}

\begin{abstract}
Raphael Silva Fagundes ${ }^{1}$
\section{Resumo}

O objetivo deste texto é analisar os atos de fala do conto de Machado de Assis em relação à crítica ao modelo retórico cultuado pelas elites letradas do século XIX. Ironizando as figuras de retórica e a fala rebuscada, nos atentaremos para o fato de que em "O Alienista" o autor deprecia a retórica como algo que esconde uma fraude, que não passa de um palavrório que busca acobertar o nada. Sendo parte de seu tempo, o bruxo do Cosme Velho age em seu contexto visando alterar as maneiras tradicionais de circulação de ideias, contribuindo para um debate extremamente consistente em sua época.
\end{abstract}

Palavras-Chave: Retórica. Machado de Assis. Século XIX.

\begin{abstract}
:
The purpose of this text is to analyze the speech acts of Machado de Assis' short story in relation to the critique of the rhetorical model adored by literate elites of the 19th century. Ironizing the figures of rhetoric and fancy speech, we will realize that in "The Alienist" the author deprecates rhetoric as something that hides a fraud, which is nothing more than a chatter that seeks to cover up nothingness. Being part of his time, the wizard of Cosme Velho acts in his context to change the traditional ways of circulating ideas, contributing to an extremely consistent debate in his time.
\end{abstract}

Keywords: Rhetoric. Machado de Assis. 19th Century

“a ciência é de fato a política executada por outros meios". (LATOUR, 1994, p.

Os modernos acreditam que um dos elementos que os diferenciam das sociedades primitivas é o fato de estas misturarem natureza e sociedade enquanto eles as separam. Mas, para o antropólogo Bruno Latour, essa separação não existe de fato. $\mathrm{O}$ trabalho de mediação, que dá sentido aos elementos da natureza descritos pelos cientistas, demonstra que jamais fomos realmente modernos (LATOUR, 1994, p. 91).

\footnotetext{
${ }^{1}$ Doutor em História pela Universidade do Estado do Rio de Janeiro (UERJ)
}

Recebido em outubro 2017/Aprovado em março 2018 
$\mathrm{Na}$ verdade, as diversas visões de mundo, incluindo, até mesmo, o saber científico, aproveitam-se da retórica para se institucionalizarem, apoiando em elementos comuns e reconhecidos socialmente para conseguir com êxito esse objetivo. Por isso, seria importante observar os dispositivos retóricos "que permitem separar não o verdadeiro do falso, mas o inqualificável cientificamente do qualificável" (FOUCAULT, 1979, p. 247). O discurso científico precisa de elementos formadores que fazem parte de uma prática discursiva encontrada em uma dada sociedade e contexto (FOUCAULT, 2007, p. 206).

São esses aspectos que iremos observar na primeira novela de um Machado de Assis maduro, como destaca Alfredo Bosi: "O Alienista" de 1882. (BOSI, 1982, p. 442). Nesse texto, identificamos uma árdua crítica do "bruxo do Cosme Velho" ao apreço pela arte do bem falar característico das elites culturais e políticas brasileiras do século XIX. Enquadrando o escritor dentro de seu contexto de produção discursiva, analisaremos como a obra se torna um ato linguístico que visa influenciar um movimento de oposição, por parte dos letrados, às maneiras tradicionais de expressão.

Como destacou Dominique Maingueneau, existem técnicas linguísticas que dão legitimidade a um discurso:

De onde é possível vir legitimidade à fala, a quem pretende dirigir-se, sob qual modalidade, em que momento, em que lugar - eis aquilo a que nenhuma enunciação pode escapar. E o escritor sabe disso melhor do que qualquer pessoa (MAINGUENEAU, 2006, p. 43).

Observar o texto como a própria gestão de seu contexto é imprescindível para a nossa pesquisa e "refletir em termos de discurso nos obriga a considerar o ambiente imediato do texto (seus ritos de escrita, seus suportes materiais, sua cena de enunciação)" (MAINGUENEAU, 2006, p. 44).

\section{Um método para estudar Machado de Assis}

John Pocock observa o efeito das linguagens políticas da época de um autor e a contribuição deste para a manutenção ou mudança dessas linguagens (POCOCK, 2003, p. 37). Seu método teve uma grande influência da teoria dos paradigmas do físico teórico Thomas Kuhn, a qual serve de instrumento para estudar a produção científica, 
indicando "toda a constelação de crenças, valores, técnicas, etc., partilhadas pelos membros de uma comunidade determinada" (KUHN, 2009, p. 220). Contudo, Pocock observa que é possível a coexistência de paradigmas (linguagens) contrários.

Para Quentin Skinner, historiador que pertence à Escola de Cambrigde, grupo que John Pocock também faz parte, não existe uma história das ideias: "Existe apenas a história das suas diferentes utilizações e das diversas intenções que presidiram ao seu uso" (SKINNER, 2005, p. 121). Além disso, busca compreender como cada autor, que participa de um projeto linguístico, baseando-se nos fatos que compõem um contexto social, comunica sua ideia em meio a uma variedade de possíveis expressões, ou seja, por que o autor utiliza determinados elementos retóricos (SKINNER, 2005, p. 123). Esses elementos são fundamentais para observarmos as formas de circulação de uma ideia.

Skinner está interessado em descobrir que "atos linguísticos" estão presentes em um texto e não no conteúdo deste em si, "tentando perceber sua coerência interna, sua relação com os outros textos e com as condições sociais que o geraram" (SKINNER, 2000, p. 332). Portanto, uma pesquisa com essa pretensão, "não pode se contentar em analisar as ideias das quais os discursos são portadores", mas como circulam e ganham consistência em uma determinada situação. E é dessa situação - que chamaremos de situação de comunicação - que emerge o sentido dos discursos, por exemplo, um enunciado "pode ter um sentido político a partir do momento em que a situação o autorizar" (CHARAUDEAU, 2006, p. 39).

Por conseguinte, para compreender a situação de comunicação, entraremos em contato com as necessidades e expectativas baseadas na interpretação de vivências anteriores além dos motivos que levam a uma ação de linguagem, visto que estes, não nascem apenas das intenções, mas das possibilidades de serem realizados. Ou seja, não é somente a intenção do orador que lhe concede a permissão de dizer, mas, também, a possibilidade de ser bem recebido por seus ouvintes (GUMBRECHT, 2003, pp. 31-34).

Skinner nos ensinou métodos que indagam os autores que estão sendo pesquisados, quais foram suas intenções ao escrever determinado texto, além de observar a conexão e as divergências entre eles e o tempo histórico que impulsionam a fabricação de um texto. Mas, como salientou também Pocock, precisamos "perguntar se um ator "sabia o que estava fazendo"” (POCOCK, 2003, p. 29), aspecto importantíssimo 
para localizar o autor em uma determinada linguagem. A partir dos textos e do nosso conhecimento da linguagem usada pelos atores, poderemos levantar hipóteses úteis para “interpretar as intenções e as ações dos próprios textos” (POCOCK, 2003, p. 38).

\section{Entre a retórica, a ciência e a literatura}

Ao usar o discurso científico, tudo parece ser neutro. No entanto, como destacou Jonas de Araújo Romualdo, "o discurso científico é uma persuasão que não se assume como tal" (ROMUALDO, 2008, p. 123). Ao analisarmos a forma de como o discurso científico se apresenta, concordamos com a tese de Maria José Coracini de que "o discurso científico, a despeito das aparências, é altamente subjetivo, constituindo, assim, um fazer persuasivo" (CORACINI, 1991, p. 20).

É como Pierre Bourdieu salientou ao refletir sobre a formação da mitologia "científica". Há dois princípios de coerência: "uma coerência reivindicada e uma coerência científica, que se afirma na multiplicidade dos sinais exteriores de cientificidade - e uma coerência oculta, mítica na origem" (BOURDIEU, 2008, p. 178). A ciência busca coerência em sinais fora da cientificidade. Isso porque, a tradição linguística erudita (que possui aparência científica) empresta seu léxico para as explicações científicas (BOURDIEU, 2008, p. 184).

A formação da ciência clássica se apoderou da retórica para se estabelecer. Deparamo-nos com esse fenômeno ao observarmos o próprio Galileu, que agiu "como hábil estrategista dentro de uma complexa rede de alianças políticas e religiosas" (WELLBERY, 1998, p. 16). David E. Wellbery traz à evidência o fato de que Galileu Galilei, na dedicatória ao seu protetor Cosimo II de Médici, "simula um drama do elogio representado através de uma cadeia de imagens eloquentes associadas à astrologia, à mitologia clássica e ao cristianismo e que chegam a remodelar as estrelas [...] como símbolos dentro desse jogo de persuasão" (WELLBERY, 1998, p. 17).

Em relação à crítica literária, alguns pesquisadores apreenderam os aspectos retóricos da obra de Machado de Assis. Luiz Costa Lima entende que a crítica à retórica empreendida por Machado é uma influência de Sterne. "Em Machado, a retórica encobre a inanidade e a mera paixão pelo brilho pelo poder"; ela tinha "o papel de encobrir o vazio, de dar-se ares de importância" (LIMA, 2009, p. 09). É uma posição 
interessante, embora não se atenta para o fato de que Machado era fruto de uma época, de uma linguagem que se fortalecia com o advento do positivismo.

Outro ponto que deve ser observado é "as situações ficcionais que ele inventou". Antonio Candido destaca um ponto que nos ajuda a compreender o fato de que, ao mesmo tempo em que Machado criticava a retórica, criticava também o positivismo, a ciência e a pretensão destes em se apoderarem do monopólio da verdade, sendo, todavia - pelo menos da maneira que se estabeleceu nos trópicos -, um mero discurso vazio. $\mathrm{O}$ narrador adota um estilo "que mantém uma espécie de imparcialidade, que é a marca pessoal de Machado, fazendo parecer duplamente intensos os casos estranhos que apresenta com moderação despreocupada" (CANDIDO, 1995, p. 22).

O "bruxo de Cosme Velho", como era conhecido, já fazia suas críticas ao discurso bem construído, porém vazio, antes de "O Alienista". Maria Elizabeth Mello propõe uma observação muito importante sobre as "Memórias Póstumas de Brás Cubas", romance escrito em 1880. Acredita que o escritor força o leitor "a refletir sobre as técnicas da narrativa tradicional, linear, imitadora da escrita da História" (MELLO, 2008, p. 189). O defunto autor está propondo uma crítica:

\footnotetext{
a morte do personagem suscita a vida do autor, para grande perplexidade do leitor. $\mathrm{O}$ que significaria essa morte que engendra a vida? $\mathrm{O}$ que seria preciso morrer para fazer viver? Teria essa metáfora alguma coisa a ver com a questão da crítica no momento, que morria simplesmente porque caíra no vazio estéril da polêmica, da retórica, da pura importação de ideias, sem reflexão adequada? (MELLO, 2008, p. 189).
}

Eugênio Vinci de Moraes destaca que Simão Bacamarte, o alienista, usa do artificialismo retórico para conseguir o que quer perante aos políticos da cidade de Itaguaí e para explicar suas teorias científicas:

\footnotetext{
Com ajuda do artificialismo retórico, o qual, a despeito da diferença que há entre suas regras e o uso de clichês e formas vaniloquêntes por parte dos agentes políticos do conto, converge para o mesmo fim, de colocar no lugar da verdade o artifício - o bordado vertiginoso e brilhante do nada (MORAES, 2013, p. 55).
}

Portanto, como destacou Alfredo Bosi, o Alienista passa a ser a descrição de uma história que "toma o ar divertido de uma comédie d'erreurs sobre a qual paira sempre a sugestão de ser o alienista o único alienado" (BOSI, 1982, p. 442), justamente 
por ser uma ciência empreendida pautada em um discurso vazio, por trás de formas grandiloquentes.

“O 'institucional' sem surpresas, esta é a essência da razão que se impõe como critério de sanidade na cabeça do alienista" (BOSI, 1982, p. 443). Por defender o institucional, o alienista tem o etos que constrói nele a imagem da verdade. A imagem do alienista é poderosa porque tem em seu favor o poder da ciência, elemento extremamente cultuado no período de Machado. Assim, Simão Bacamarte tem a capacidade de prender tanto os representantes da política, quanto o representante da Igreja, como o Padre Soares.

Por isso, é importante que destaquemos as considerações de Roberto Gomes, quando aponta que a tensão fundamental do texto de Machado está no "poder da ciência que a retórica científica pretende mascarar". Portanto, não critica apenas a retórica, mas a "concepção racionalista e positivista da ciência" e o "poder de todo e qualquer saber que pretenda apresentar-se como rigorosamente objetivo" (GOMES, 1993, p. 153).

Nosso foco aqui será demonstrar que Machado de Assis não criticava, exatamente, a ciência, mas a maneira pela qual o cientificismo foi apropriado ${ }^{2}$ pela "nova geração", por meio de frases pomposas, desprovidas de bases científicas, escondendo-se por trás de um modelo retórico característico da herança letrada oitocentista. Seu alvo era o culto à eloquência, um elemento que ainda se mostrava dominante na literatura feita por aqueles que "ainda cheiram ao puro leite romântico", sendo, por conseguinte, uma das razões para que não houvesse "por ora no nosso ambiente a força necessária à invenção de doutrinas novas” (ASSIS, 1994, p. 04)

\section{Machado de Assis entre duas linguagens}

Em “o Alienista”, publicado pela primeira vez em 1882, Machado conta a história do Dr. Simão Bacamarte, um médico que cultua a ciência. Ele funda, com o aval da Câmara, a Casa Verde, um hospício na vila de Itaguaí. A partir daí, o dedicado médico não cansa de pôr suas teorias em prática, colocando grande parte dos cidadãos da vila no hospício.

\footnotetext{
${ }^{2}$ As pesquisas recentes substituem pelo conceito de apropriação das ideias estrangeiras o que antes era visto como imitação, "o que significa supor dos agentes capacidade de escolha interessada de idéias conforme experiências e os dilemas próprios”. (ALONSO, 2009, p. 87)
} 
No capítulo "Torrente de loucos", o narrador começa a descrever os alienados que foram internados na Casa Verde por meio de um critério experimental do nosso alienista Bacamarte. O primeiro louco descrito sofre de retórica:

O Padre Lopes confessou que não imaginara a existência de tantos doidos no mundo, e menos ainda o inexplicável de alguns casos. Um, por exemplo, um rapaz bronco e vilão, que todos os dias, depois do almoço, fazia regularmente um discurso acadêmico, ornado de tropos, de antíteses, de apóstrofes, com seus recamos de grego e latim, e suas borlas de Cícero, Apuleio e Tertuliano. $\mathrm{O}$ vigário não queria acabar de crer. Quê! um rapaz que ele vira, três meses antes, jogando peteca na rua! (ASSIS, 2008, p. 10).

Machado pertencia a uma geração de letrados que buscava depreciar alguns elementos reconhecidos como ultrapassados. $\mathrm{O}$ culto à retórica, ao bem falar, era um desses elementos.

Para Silvio Romero, grande crítico da época, o período da literatura brasileira que se estende de 1850 a 1870 é visto como intermediário, "com veleidades retóricas de estafado classicismo". José Veríssimo vai dizer que a literatura de seu tempo está começando a adotar "um critério mais largo que as regras da retórica clássica". 3

Roberto Acízelo de Souza destaca uma passagem da obra de Aluísio de Azevedo escrita em 1881, que mencionava "o caráter involuntariamente cômico da oratória, a prática social fundamentada no aprendizado retórico":

Limpou a superfície dos lábios com o guardanapo dobrado, que pousou depois vagarosamente sobre a mesa; passou a enorme unha do seu dedo mínimo no desfibrado bigode, e, fitando uma compoteira de doce de pacovas - erguida a mão direita, na atitude de quem mostra uma pitada — declamou com ênfase:

- Meus ilustres senhores e respeitabilíssimas senhoras!

Houve uma pausa.

- Não poderíamos, pela ventura, terminar satisfatoriamente esta, tão pequena quão antiga e tradicional festa de família, sem brindarmos uma pessoa respeitável e digna de toda a consideração e... respeito! Por isso... eu! eu, senhores, o mais insignificante, mais insuficiente de todos nós!...

— Não apoiado! Não apoiado!

- Apoiado! Dizia o Cordeiro com os olhos vidrados.

- Sim - eu, cuja voz não foi bafejada pelo dom sagrado da eloquência! Eu, que não possuo a palavra divina dos Cícero, dos Demóstenes, dos Mirabeau, dos José Estevão, et cetera, et cetera! eu, meus senhores! vou brindar... a quem?!

E desenrolou um repertório interminável de fórmulas misteriosas apropriadas à situação, exclamando no fim, cheio de sibilos:

- Inútil dizer o nome!...

\footnotetext{
${ }^{3}$ As duas passagens foram retiradas de: (SOUZA, 1999, p. 26).
} 
Todos perguntavam entre si com quem seria o brinde. Houve teimas; fizeram-se apostas.

- Mais do que inútil é dizer o nome, prosseguiu o discursador, saboreando o efeito da sua impenetrável alusão, mais do que inútil é dizer o nome! porquanto já sabeis de sobra que falo com referência à excelentíssima $\mathrm{Sr}^{\mathrm{a}}$ a Dona... (nova pausa) Maria Bárbara Mendonça de Melo!...

Fez-se uma balbúrdia de exclamações (Azevedo, 1992, p. 123-124).

Em o “Ateneu”, de Raul Pompeia, posturas positivas e negativas sobre a oratória alternam-se nos personagens do romance. No entanto, a retórica é vista em certa situação como um discurso vazio:

\begin{abstract}
com todos os requisitos da oratória, pureza, clareza, correção, precisão, menos uma coisa - a ideia; Cícero tempestade - verborrágico, por paus e por pedras, precipitando-se pela fluência como escada abaixo [...]; Cícero fraqueza - positivo, indispensável para o encerramento das discussões [...]; Cícero sacerdócio - sacerdotal, solene, orando em trêmulo [...] (Pompeia, 1981, p. 143-144).
\end{abstract}

Ou seja, Machado pertencia a um circuito linguístico que produzia um discurso contestatório ao modelo tradicional de circulação e produção do saber. Seus textos são atos de fala que contribuem para o fortalecimento desse circuito.

A chamada "geração de 1870" apropriou-se de matrizes europeias introduzindo no Brasil o naturalismo, o evolucionismo e o cientificismo por meio de uma crítica que visava "contribuir para a construção da nacionalidade" (VENTURA, 1991, p. 11). Deste modo, esse movimento anti-romântico tinha o objetivo de confrontar um modelo de nação construída sobre a visão literária que predominava no Segundo Reinado que, esteticamente, aproveitou-se da herança retórica, proveniente do ensino jesuítico de tempos coloniais, capaz de construir argumentos potentes (SOUZA, 1999, p. 24).

Esse modelo de identidade nacional tornou-se legítimo e institucionalizado pelos membros do Instituto Histórico e Geográfico Brasileiro (GUIMARÃES, 2007, p. 103), associação fundada em 1838 com o objetivo de coligir, metodizar, arquivar e publicar documentos para a escrita da história do Brasil. Suas fileiras eram compostas por homens da mais alta estirpe das letras do país, assim como da política. Os membros dessa associação carioca produziam odes e discursos nas sessões magnas de aniversário da associação, em que exaltavam o imperador e fortaleciam um modelo de nação centralizada, pautada nos preceitos monárquicos constitucionais. 
Carlos Honório Figueiredo, primeiro secretário interino do Instituto em 1876, discursa sobre a fundação da capela imperial por D. João VI, exaltando aquele acontecimento histórico:

foi a arena onde se mostrou com toda a sua pompa o gênio brasileiro. Podemos afirmar com testemunhos valiosos, com todo o orgulho da verdade, que nenhum pregador transatlântico excedeu os oradores brasileiros. A riqueza da dicção reunia-se a pureza de estilo e força da argumentação; e, para que não faltasse uma só beleza, a doçura, a amenidade da expressão, aumentava os encantos e a magia da ação (FIGUEIREDO, 1876, p. 482).

O padre Antonio Vieira, ícone da oratória barroca que muitas marcas deixou na cultura letrada luso-brasileira, era louvado pelas elites culturais que compunham o $\mathrm{IHGB}^{4}$ e deveria ser lembrado de modo a promover "na mocidade o desejo de cultivar as letras" (DOMINGOS, 2009, p. 168). Sua habilidade com as palavras vem à tona. O padre seiscentista é citado por Joaquim Norberto de Souza e Silva já nos últimos dias do Império como uma voz eloquente da liberdade, potente, principalmente porque proveniente do púlpito:

A colônia, apesar de escrava, tinha tido por três séculos a sua voz eloquente e, o que mais é - voz livre, pois no púlpito - a única tribuna do país, - era dado o estratagema de certas alegorias; pregava-se à vista de numeroso auditório - aos peixes! (SILVA, 1886, p. 492).

A eloquência possuía uma função política capaz de unir a nação e pôr fim aos conflitos internos que assolavam o Brasil nos anos de 1830. Joaquim Manoel de Macedo, autor de "A Moreninha" e orador oficial do IHGB, em seu discurso em homenagem ao sócio falecido Gabriel Rodrigues dos Santos, anuncia: "Fez-se desde logo notável pela eloquência com que sustentava os princípios liberais [...] a eloquência era nele um dom da natureza, e se ostentava sem esforço, sem pretenções, sem trabalho" (MACEDO, 1930, p. 493).

Como destacou a professora Lucia Maria Paschoal Guimarães, o "bando de ideias novas", nas palavras de Sílvio Romero, que invadiu o Império a partir dos finais dos anos de 1860, “não passou pelas cercanias do Largo do Paço, onde o Instituto se

\footnotetext{
${ }^{4}$ Instituto Histórico e Geográfico Brasileiro fundado em 1838 com o objetivo de coligir, metodizar, arquivar e publicar documentos para a escrita da História do Brasil
} 
situava” (GUIMARÃES, 2011, pp. 152-153). É o próprio Joaquim Norberto de Souza e Silva que nos demonstra essa questão:

\begin{abstract}
A nova geração, transviada das sendas do idealismo, perdida a estrela polar do patriotismo, mal tem dado algumas produções dignas de si, e o realismo, sem o fogo do amor da pátria, falta de inspiração divina, agoniza debatendose de encontro as frias barreiras do positivismo - sem alma porque não tem a crença da imortalidade - sem espaço, porque não vê o infinito - sem luz, porque não se inspira de Deus e em Deus (SILVA, 1886, p. 496).
\end{abstract}

Dessa forma, duas linguagens dominantes digladiavam-se nesse momento. Machado de Assis poderia optar por uma das duas. No entanto, em termos discursivos, vai se colocar arduamente contrário a tudo que representava as antigas formas retóricas, formas que acreditava ser predominante no meio político e que, se utilizadas por alguém, seria sempre uma maneira de esconder o falso. Essa situação nos lembra uma passagem de Wittgenstein: "O significado de uma palavra é o seu uso na linguagem" (WITTGENSTEIN, 2009, p. 38). As coisas se tornam falsas não pelas coisas em si, mas pela maneira que são representadas. $\mathrm{O}$ uso de palavras, estratégias e conceitos de uma linguagem em depreciação acabam por depreciar o objeto descrito.

Sendo assim, era necessário construir explicações não mais recorrendo "à mesma retórica clássica, aos mesmos exemplos - os positivos retirados da história romana, os negativos, da realidade próxima, a rebelião escrava do Haiti e as revoltas regenciais" (ALONSO, 2009, p. 83-119). Era uma nova era, e novas fontes de inspiração europeia entravam em cena, parindo, aqui nos trópicos, uma nova linguagem, isto é:

uma estrutura complexa que abrange um vocabulário, uma gramática, uma retórica e um conjunto de usos, pressupostos e implicações, que existem juntos no tempo e são empregáveis por uma comunidade semi-específica de usuários de linguagem para propósitos políticos, que permite, e por vezes se prolonga até, a articulação de uma visão de mundo ou de uma ideologia (POCOCK, 2006, pp. 83-84).

Para o médico Simão Bacamarte, que internava algumas pessoas pelo fato de serem "eloquentes demais", ou seja, por usarem de forma dissimulada a fala pomposa, a vaniloquência era um sintoma de distúrbio cerebral, como no caso de Martim Brito, que prolata um discurso rico em ornamentos após a chegada de D. Evarista, mulher de Bacamarte, que retorna do Rio de Janeiro com sua comitiva: 
Três horas depois cerca de cinquenta convivas sentavam-se em volta da mesa de Simão Bacamarte; era o jantar das boas-vindas. D. Evarista foi o assunto obrigado dos brindes, discursos, versos de toda a casta, metáforas, amplificações, apólogos. Ela era a esposa do novo Hipócrates, a musa da ciência, anjo, divina, aurora, caridade, vida, consolação; trazia nos olhos duas estrelas segundo a versão modesta de Crispim Soares e dois sóis no conceito de um vereador. $\mathrm{O}$ alienista ouvia essas coisas um tanto enfastiado, mas sem visível impaciência. Quando muito, dizia ao ouvido da mulher que a retórica permitia tais arrojos sem significação. D. Evarista fazia esforços para aderir a esta opinião do marido; mas, ainda descontando três quartas partes das louvaminhas, ficava muito com que enfunar-lhe a alma. Um dos oradores, por exemplo, Martim Brito, rapaz de vinte e cinco anos, pintalegrete acabado, curtido de namoros e aventuras, declamou um discurso em que o nascimento de D. Evarista era explicado pelo mais singular dos reptos. "Deus, disse ele, depois de dar o universo ao homem e à mulher, esse diamante e essa pérola da coroa divina (e o orador arrastava triunfalmente esta frase de uma ponta a outra da mesa), Deus quis vencer a Deus, e criou D. Evarista."

[...] o alienista sorria agora para o Martim Brito e, levantados todos, foi ter com ele e falou-lhe do discurso. Não lhe negou que era um improviso brilhante, cheio de rasgos magníficos. Seria dele mesmo a ideia relativa ao nascimento de D. Evarista ou tê-la-ia encontrado em algum autor que?... Não senhor; era dele mesmo; achou-a naquela ocasião e pareceu-lhe adequada a um arroubo oratório. De resto, suas ideias eram antes arrojadas do que ternas ou jocosas. Dava para o épico. Uma vez, por exemplo, compôs uma ode à queda do Marquês de Pombal, em que dizia que esse ministro era o "dragão aspérrimo do Nada" esmagado pelas "garras vingadoras do Todo"; e assim outras mais ou menos fora do comum; gostava das ideias sublimes e raras, das imagens grandes e nobres...

"- Pobre moço! pensou o alienista. E continuou consigo: - Tratase de um caso de lesão cerebral: fenômeno sem gravidade, mas digno de estudo..." (ASSIS, 2008, pp. 23-24).

E, assim, o trancafiou nas masmorras de seu hospício.

Outro condenado a passar alguns dias na Casa Verde foi um tal de Coelho, "um homem de excelente caráter", mas "ele amava a boa palestra, a palestra comprida, gostada a sorvos largos" (ASSIS, 2008, p. 25).

Contudo, na história contada por Machado de Assis, a retórica política recebe um tratamento especial. A população de Itaguaí, indignada com o reinado de terror do alienista, alia-se ao barbeiro Porfírio que dizia ser "preciso derrubar o tirano" justamente no dia em que Coelho foi preso: "Não me dirão em que é que o Coelho é doido?"

Porfírio levanta a bandeira da rebelião que ficou conhecida como a "revolta da Canjica” e vai à Câmara exigir o fim do governo de Terror de Simão Bacamarte: 


\begin{abstract}
por terra a Casa Verde- “essa Bastilha da razão humana"- expressão que ouvira a um poeta local e que ele repetiu com muita ênfase. Disse, e, a um sinal, todos saíram com ele. Imagine-se a situação dos vereadores; urgia obstar ao ajuntamento, à rebelião, à luta, ao sangue. Para acrescentar ao mal um dos vereadores que apoiara o presidente ouvindo agora a denominação dada pelo barbeiro à Casa Verde_ - "Bastilha da razão humana"-achou-a tão elegante que mudou de parecer. Disse que entendia de bom aviso decretar alguma medida que reduzisse a Casa Verde; e porque o presidente, indignado, manifestasse em termos enérgicos o seu pasmo, o vereador fez esta reflexão: - Nada tenho que ver com a ciência; mas, se tantos homens em quem supomos são reclusos por dementes, quem nos afirma que o alienado não é o alienista? (ASSIS, 2008, p. 25).
\end{abstract}

O narrador cria a imagem de que a política funciona por meio de referências e exemplos de sua própria história, dos grandes acontecimentos que abalaram a humanidade. Basta saber utilizar a referência certa que o político se identificará e se dobrará à exigência. A política não raciocina por meio do fato, mas das estratégias retóricas utilizadas no debate político.

A partir daí podemos refletir sobre o jogo de linguagem no final dessa passagem que visa desencadear um sentido lógico. José Murilo de Carvalho resgata, para destacar o estilo retórico da cultura letrada brasileira, um dos discursos mais famosos da história do Senado do Império. O pronunciamento, que ficou conhecido como "sorites de Nabuco", foi pronunciado por José Tomás Nabuco de Araújo em 1868, em meio a uma crise política que marcava o retorno dos conservadores ao poder:

O Poder Moderador pode chamar a quem quiser para organizar ministérios; esta pessoa faz a eleição, porque há de fazê-la; esta eleição faz a maioria. Eis aí o sistema representativo do nosso país (CARVALHO, 2000, pp. 127-128).

A estratégia argumentativa do político que acatou as reivindicações de Porfírio não se valeu do sorites, mas da indução, embora o primeiro tenha "grande analogia na substância” (ANTONIO, 1779, p. 108) com o segundo. As duas estratégias retóricas fazem parte do jogo de linguagem fundamental na composição de um discurso persuasivo.

Continuemos a observar como o narrador descreve as manifestações dos políticos para com os rebelados de Itaguaí:

Sebastião Freitas, o vereador dissidente, tinha o dom da palavra e falou ainda por algum tempo, com prudência mas com firmeza. Os colegas estavam atônitos; o presidente pediu-lhe que, ao menos, desse o exemplo da ordem e 
do respeito à lei, não aventasse as suas ideias na rua para não dar corpo e alma à rebelião, que era por ora um turbilhão de átomos dispersos. Esta figura corrigiu um pouco o efeito da outra: Sebastião Freitas prometeu suspender qualquer ação, reservando-se o direito de pedir pelos meios legais a redução da Casa Verde. E repetia consigo namorado:-Bastilha da razão humana! (ASSIS, 2008, pp. 26-27).

A princípio parece que seria a vitória da política sobre a ciência, ou da retórica tradicional sobre o conhecimento científico. Até a figura de linguagem usada pelo presidente para convencer Sebastião Freitas ("um turbilhão de átomos dispersos") é proveniente do meio científico. Mas a grande questão é que Machado ironiza o fato de o político ser enfeitiçado pelas belas palavras, e não pela importância do fato em si.

Dessa maneira, todas as atitudes empreendidas pelos membros da Câmara, ou são acompanhadas, ou consequência do ato do bem dizer. "Os vereadores [...] votaram uma petição ao vice-rei para que mandasse dar um mês de soldo aos dragões, 'cujo denodo salvou Itaguaí do abismo a que o tinha lançado uma cáfila de rebeldes"” (ASSIS, 2008, p. 31). Machado de Assis leva ao pé da letra o fato de figuras de retóricas serem um fator persuasivo (GUIMARÃES, 2004, p. 150).

Mas a retórica não se resume apenas a figuras. Quando o barbeiro assumiu o poder da Câmara, através de uma investida apoiada pelos Dragões, pronuncia um discurso com elementos retóricos destacáveis. Primeiramente devemos nos atentar para o fato de que Porfírio sempre foi uma figura que desejava o poder político, mas não tinha influência na vila de Itaguaí. Desse modo, sua proficiência retórica é uma consequência de seu desejo de ser político, como se fosse algo congênito. Machado faz parecer que uma coisa leva a outra.

Começa apontando o inimigo, enquadrando-o dentro de conceitos pútridos da política que os ouvintes mais compreendem. "Uma câmara corrupta e violenta" (ASSIS, 2008, p. 31). A corrupção é um dos elementos mais compartilhados no senso comum para depreciar um político. Para o orador seria uma espécie de eidos, um lugar próprio de onde se extraem os argumentos para um discurso do gênero deliberativo. Os principais temas desse tipo de gênero do discurso, que são as "decisões a serem tomadas em benefício público", são expostas de forma negativa (MOSCA, 2004, p. 30).

O semiolinguísta Patrick Charaudeau destaca o fato de que "persuadir um auditório consiste em produzir nele sentimentos que o predispõe o ponto de vista do orador" (CHARAUDEAU, 2007, p. 242). Sendo assim, Porfírio irá destacar 
imediatamente: "foi-me confiado o mando supremo" (ASSIS, 2008, p. 32). Mas esse ponto de vista deve vir atrelado à forma pela qual o sujeito se representa que, oportunamente, deve ser capaz de despertar emoções: "Contai com o meu sacrifício". Dessa maneira, Porfírio cria um ethos que promove a identificação do auditório com a pessoa do orador e pede aos itaguaienses que lhe "rodeeis de confiança", que lhe “auxilieis em restaurar a paz". E, em seguida, desenvolve o sentimento de esperança, como o célebre padre Antonio Vieira, ícone da retórica luso-brasileira, que uma vez o fez no Sermão dos Bons Anos ao assegurar anos prósperos ao governo de D. João IV após a Restauração de Portugal: "ficai certos de que a coroa será por nós" (VIEIRA, 1998). O líder político da narrativa conclui o seu discurso assinando o documento como “O Protetor da vila em nome de Sua Majestade e do povo”.

No final de sua empreitada como chefe político, Porfírio acaba entrando na trama do poder, esquecendo o povo e si prendendo aos seus interesses. Uma maneira que Machado encontrou de depreciar o mau uso da retórica, de evidenciar que ela não passa de um discurso vazio que esconde as reais intenções do falante. Contudo, em seu enunciado inaugural, o barbeiro conseguiu fazer com que a instância política pensasse como a instância cidadã, de modo que esta se identificasse com o orador. Para Charaudeau, essa é a essência do mentir verdadeiro no discurso político (CHARAUDEAU, 2006, p. 106).

Além disso, temos que nos atentar para o fato de que a retórica, principalmente quando adotada em termos literários, é abordada como "um sistema mais ou menos bem elaborado de formas de pensamento e de linguagem, as quais podem servir à finalidade de quem discursa para obter, em determinada situação, o efeito que pretende" (LAUSBERG, 2004, p. 75). E as atitudes retóricas de Porfírio adotaram essa estratégia desde o início quando ele exige da Câmara uma atitude.

Machado de Assis conhece os elementos da retórica muito bem. O personagem João Pina também se vale da retórica quando acusa Porfírio e põe fim ao reinado do barbeiro: "um intruso eivado das más doutrinas francesas, e contrário aos sacrossantos interesses de Sua Majestade". Trata-se de um argumento que coloca em conflito o profano e o sagrado. A estratégia usada é a de demonizar o inimigo para despertar também a indignação. Aristóteles orienta o orador sobre tal sentimento, "dos que a provocam", "suas causas e disposições em que nos encontramos quando nos 
indignamos". Segundo o filósofo grego, “indignamo-nos, vendo os maus beneficiarem da riqueza, do poder e de vantagens análogas" (ARISTÓTELES, s/d., p. 145). Por isso, não só João Pina cria essa imagem maléfica de Porfírio, mas o próprio narrador o descreve de maneira maquiavélica.

\title{
A fraude de um cientista retórico
}

Mas Machado de Assis não critica apenas a tradição política do país em dar ênfase à retórica. Todos que usam do artificialismo retórico é alvo do escritor. No fim do conto, o Dr. Simão Bacamarte percebe que está enlouquecendo e si tranca no seu escritório para estudar a si mesmo. Após dezessete meses vem a falecer. Mas enquanto vivo, Assis encontrou uma maneira de depreciar o cientista ao colocar na sua boca palavras eloquentes, que, por sua vez, dissimulavam o conhecimento científico, isto é, acobertavam uma ciência fraudulenta.

Assim que D. Evarista viaja em comitiva para cidade do Rio de Janeiro, Bacamarte manda chamar o boticário seu amigo, o Sr. Crispim Soares. Ao explicar que sua pesquisa trata de uma experiência e não ainda de uma teoria diz: "A loucura, objeto dos meus estudos, era até agora uma ilha perdida no oceano da razão; começo a suspeitar que é um continente" (ASSIS, 2008, p. 16).

Em seguida, o cientista imarcescível explica "compridamente a sua ideia":

\begin{abstract}
Os exemplos achou-os na história e em Itaguaí mas, como um raro espírito que era, reconheceu o perigo de citar todos os casos de Itaguaí e refugiou-se na história. Assim, apontou com especialidade alguns personagens célebres, Sócrates, que tinha um demônio familiar, Pascal, que via um abismo à esquerda, Maomé, Caracala, Domiciano, Calígula, etc., uma enfiada de casos e pessoas, em que de mistura vinham entidades odiosas, e entidades ridículas (ASSIS, 2008, p. 16).
\end{abstract}

É muito comum encontrarmos nos discursos políticos do século XIX, referências constantes aos antigos pensadores e figuras históricas. Aureliano Coutinho, grande político de meados do Oitocentos e articulador do golpe da Maioridade, em um discurso pronunciado no IHGB que visava à construção da imagem de D. Pedro II como um soberano protetor das artes, letras e ciências que conduziria o progresso da nação, cita diversos exemplos históricos: 
Se olharmos para a antiguidade encontraremos aí os Felipes e Alexandres em Macedonia; os Augustos, os Trajanos, os Marco Aurelios em Roma; e ao lado destes Grandes príncipes os protegidos por eles, os Aristóteles, os Xenocrates, os Areus, os Diões, e os Sextus (COUTINHO, 1916, p. 578).

A citação, da maneira que é feita aqui, tem como objetivo retórico o exemplo. Fábio Quintiliano explica que os gregos chamavam os exemplos de Paradigmas, “compreendendo geralmente nesta palavra toda a confrontação de coisas semelhantes, e especialmente a dos fatos históricos" (QUINTILIANO, 1788, pp. 350-351). Para Quintiliano, o exemplo é "a lembrança, que fazemos de um fato, ou acontecido, ou que podia acontecer, útil para persuadir o que intentamos" (QUINTILIANO, 1788, p. 352). O Dr. Bacamarte achou perigoso usar os casos de Itaguaí e preferiu usar os exemplos da História, muito comum no discurso político da época.

Mas o médico usa outros procedimentos retóricos repletos de figuras de linguagem para desenvolver o seu raciocínio:

\footnotetext{
Suponho o espírito humano uma vasta concha, o meu fim, Sr. Soares, é ver se posso extrair a pérola, que é a razão; por outros termos, demarquemos definitivamente os limites da razão e da loucura. A razão é o perfeito equilíbrio de todas as faculdades; fora daí insânia, insânia e só insânia (ASSIS, 2008, p. 16).
}

Para Eugênio Vinci de Moraes, Machado quer explicitar que "todas essas formas de expressão servem para legitimar uma ciência fraudulenta”. Dessa maneira, o "cientista fundira-se ao estadista virtuoso" (MORAES, 2013, p. 53), apoderando-se de uma maneira expressiva tradicional usada no meio político. Além disso, ao longo do conto, vemos a relação entre ciência e política vir à tona repetidas vezes, o que nos leva à confirmação da reflexão de Bruno Latour citada no início deste texto.

Já para as linhas finais da obra, Bacamarte percebe que seus métodos científicos não estavam sendo eficientes e resolveu libertar grande parte dos alienados com base na ideia de que a verdadeira doutrina deveria ser "admitir como normal e exemplar o desequilíbrio das faculdades, e como hipóteses patológicas todos os casos em que aquele equilíbrio fosse ininterrupto". Assim, o alienista reconhece a eloquência de Martim Brito que foi preso pelo elogio dado a sua esposa. Agora em liberdade, Brito faz um novo discurso, desta vez em honra ao insigne médico, "cujo altíssimo gênio, 
elevando as asas muito acima do sol, deixou abaixo de si todos os demais espíritos da terra". Com sua grandeza descrita pela eloquência, podemos pensar que Bacamarte não se incomoda por causa do seu ego, mas pela nova "verdade científica" que passou a defender a qual não entende mais como "normal" o "perfeito equilíbrio das faculdades mentais". E, então, declara:

- Agradeço as suas palavras, retorquiu-lhe o alienista, e ainda me não arrependo de o haver restituído à liberdade (ASSIS, 2008, p. 41).

\section{Conclusão}

O fato é que a imparcialidade de Machado de Assis deve ser pensada em alguns aspectos, já que é fácil situá-lo em um contexto em que um discurso letrado visava depreciar um modelo de pensamento anterior que, por sua vez, venerava a eloquência. Ele não estava fora desse contexto linguístico. Por isso, não critica a ciência, mas o poder que ela pode exercer sobre todos quando é aplicada de forma fraudulenta. E a maior evidência da fraude é o discurso pomposo. É se vestir com aquilo que o escritor mulato criticava, isto é, estratégias retóricas que escondem a ausência de conhecimento.

$\mathrm{O}$ alvo de Machado de Assis é a tradicional maneira pela qual as ideias circulavam no Brasil. Se indignava contra o estilo retórico das elites letradas, embora não descartasse a importância do estilo para a literatura, tanto que travou uma contenda com Silvio Romero, na qual enfatizava que o crítico literário não possuía estilo, elemento que para o bruxo de Cosme Velho era a "condição indispensável" de um escritor, mas logo abandonou por "tédio à controvérsia" (MELLO, 2008, p. 180).

Machado preferia uma literatura crítica a uma crítica literária. Desse modo, em seus contos levantava questões que colocavam em cheque a literatura de seu tempo com humor e ironias. O Alienista é um conto que evidencia esse estilo. Ironizando o que Sérgio Buarque de Holanda classificou já no século XX como sendo uma característica do brasileiro:

[...] o amor à frase sonora, ao verbo espontâneo e abundante, à erudição ostentosa, à expressão rara. É que para bem corresponder ao papel que, mesmo sem o saber, lhe conferimos, a inteligência há de ser ornamento e prenda, não instrumento de conhecimento e de ação (HOLANDA, 2005, p. 83). 
Para o brasileiro, de acordo com o sociólogo, o saber não servia como um instrumento útil capaz de agir na realidade, na natureza, como se supõe do conhecimento científico. Ele é apenas ornamento, estilo. O discurso de apreciação a tudo que era científico no qual Machado de Assis estava submerso jamais poderia interligar a ciência à retórica, principalmente pelo fato de a primeira ser um instrumento da modernidade capaz de pôr à antiga forma de saber em xeque. Por isso, não se faz ciência quando se faz retórica.

No entanto, hoje já se compreende que a ciência sempre se valeu da retórica para se firmar, como o discurso supracitado de Galileu Galileu em homenagem ao seu protetor da Casa Médici. Porém, no contexto em que Assis estava inserido, essa relação não poderia ser tão amistosa, justamente pela necessidade iluminista de o moderno ter sempre a intenção de depreciar o tradicional. 


\section{REFERENCIAS}

\section{Fontes primárias}

ANTONIO, Fr. Sebastião de Santo. Ensaio de retórica, conforme o método e doutrina de Quintiliano. Lisboa: Oficina Luisiana, 1779. p. 108. Disponível em: https://books.google.com.br/books?id=RH7iFn6Ls6IC\&pg=PA107\&lpg=PA107\&dq=S orites $+\mathrm{C} \% \mathrm{C} 3 \% \mathrm{ADcero}+\mathrm{e}+$ quintiliano $\&$ source $=\mathrm{bl} \&$ ots $=\mathrm{PiR} 3 \mathrm{NidcQ}$ \&sig=4EoaHeIqFv $\underline{\text { sLrOryMvafpUt53bU\&hl }=\mathrm{pt}-}$

$\underline{B R \& s a=X \& v e d=0 a h U K E w i y i q e Q 67 D V A h W K j J A K H Z v C B x A Q 6 A E I R T A E \# v=o n e p a ~}$ ge\&q=sorites $\% 20 \mathrm{C} \% \mathrm{C} 3 \%$ ADcero $\% 20 \mathrm{e} \% 20$ quintiliano\&f=false. Acesso em: 30 de jul. de 2017.

ASSIS, Machado. "A nova geração". Obra completa. Rio de Janeiro: Nova Aguiar, 1994.

O alienista. Rio de Janeiro: Rovelle, 2008.

AZEVEDO, Aluísio. O mulato. São Paulo: Ática, 1992.

COUTINHO, Aureliano de Souza e Oliveira. "Discurso d'abertura recitado pelo VicePresidente". R.IHGB, Rio de Janeiro, 3 ed. Tomo II, Imprensa Nacional, 1916. p. 578. (1840). Disponível em http://www.ihgb.org.br/rihgb/ rihgb1840t0002c.pdf. Acesso em: 10 de março de 2011.

FIGUEIREDO, Carlos Honório. "Relatório do $1^{\mathrm{o}}$ secretário interino". In: R. IHGB, Rio de Janeiro, Tomo XXXIX, vol. 2, Garnier, 1876, p. 482. Disponível em: http://www.ihgb.org.br/rihgb/rihgb1876t00392c.pdf. Acesso em: 18 de agosto de 2015. MACEDO, Joaquim Manoel de. Discurso do orador. R.IHGB, Rio de Janeiro, 2 ed. Tomo XXI, Imprensa Nacional, 1930 (1858). p. 493. Disponível em http://www.ihgb.org.br/rihgb/rihgb1858t0021c.pdf. Acesso em: 20 de agosto de 2011 
POMPEIA, Raul. O Ateneu; crônica de saudades. Introdução, estabelecimento do texto e notas de Afrânio Coutinho \& Maria Filgueiras. Rio de Janeiro: MEC-FENAME / OLAC / Civilização Brasileira, 1981.

QUINTILIANO, M. Fabio. Instituiçoens Oratórias. Trad: Jeronymo Soares Barbosa. Tomo Primeiro, Coimbra: Imprensa Real da Universidade, 1788.

SILVA, Joaquim de Souza e. "Discurso de abertura". In: R.IHGB, Rio de Janeiro, Tomo XLIX, vol. 2, Lammert \& C., 1886. p. 492. Disponível em:

http://www.ihgb.org.br/rihgb/ rihgb1886t00492c.pdf. Acesso em: 12 de agosto de 2015. VIEIRA, Pe. Antonio. “Sermão dos Bons Anos”. In: Sermões, Padre Antônio Vieira, Erechim: Edelbra, 1998. Acesso: 06 de janeiro de 2014.

http://www.literaturabrasileira.ufsc.br/documentos/?action=download\&id= 28864 .

\section{Livros e artigos}

ALONSO, Angela. Apropriação de ideias no Segundo Reinado. KEILA, Grinberg, SALLES, Ricardo (Org). O Brasil imperial. 1831-1870. Rio de Janeiro: Civilização Brasileira, 2009, p. 83-118. v.3.

ARISTÓTELES. Arte Retórica e Poética. Rio de Janeiro: Tecnoprint, s/d.

BOSI, Alfredo. A máscara e a fenda. Machado de Assis: antologia e estudos. São Paulo: Ática, 1982.

BOURDIEU, Pierre. A Economia das Trocas Linguísticas: o que falar quer dizer. 2 ed. São Paulo: Edusp, 2008.

CANDIDO, Antonio. Esquema Machado de Assis. Vários Escritos. $3^{\text {a }}$ ed. rev. e ampl. - São Paulo: Duas Cidades, 1995.

CARVALHO, José Murilo de. História intelectual no Brasil: a retórica como chave de leitura. In: Topoi, Rio de Janeiro, n. 1, pp. 123-152, 2000.

CHARAUDEAU, Patrick. O Discurso Político. Trad: Fabiana Komesu e Dilson Ferreira da Cruz. São Paulo: Contexto, 2006.

Pathos e discurso político. MACHADO, Ida Lucia; MENEZES, William; MENDES, Emília. (orgs.). As Emoções no Discurso. Vol. 1. Rio de Janeiro: Lucerna, 2007. 
CORACINI, Maria José Rodrigues Faria. Um fazer persuasivo: o discurso subjetivo da ciência. São Paulo: Edpuc; Campinas: Pontes, 1991.

DOMINGOS, Simone Tiago. Política e memória: a polêmica sobre os jesuítas na Revista do IHGB e a política imperial (1839-1886). Dissertação de Mestrado, Campinas: Unicamp, 2009.

FOUCAULT, Michel. A Arqueologia do saber. 7 ed. Trad: Luiz Felipe Baeta Neves. Rio de Janeiro: Forense Universitária, 2007.

FOUCAULT, Michel. Microfísica do poder. 23 ed. Trad: Roberto Machado. Rio de Janeiro: Graal, 1979.

GOMES, Roberto. O Alienista: loucura, poder e ciência. In: Tempo Social. Revista de Sociologua, USP, São Paulo, 5 (1-2), p. 145-160, 1993.

GUIMARÃES, Elias. Figuras de retórica e argumentação. MOSCA, Lineide do Lago Salvador. (org.) Retóricas de Ontem e de Hoje. 3 ed. São Paulo: Humanitas, 2004. GUIMARÃES, Manoel Salgado. A disputa pelo passado na cultura histórica oitocentista no Brasil. In: José Murilo de Carvalho. (org.). Nação e Cidadania no Império: novos horizontes. Rio de Janeiro: Civilização Brasileira, 2007. GUIMARÃES, Lucia Maria Paschoal. Debaixo da Imediata Proteção Imperial: Instituto Histórico e Geográfico Brasileiro (1838-1889). 2 ed. São Paulo: Annablume, 2011.

GUMBRECHT, Hans Ulrich. As Funções da Retórica Parlamentar na Revolução Francesa: estudos preliminares para uma pragmática histórica do texto. Trad: Georg Otte. Belo Horizonte: UFMG, 2003.

HOLANDA, Sérgio Buarque de. Raízes do Brasil. 26 ed. São Paulo: Cia das Letras, 2005.

KUHN, Thomas. A Estrutura das Revoluções Científicas. Trad: Beatriz Vianna Boeira e Nelson Boeira. São Paulo: Perspectiva, 2009.

LATOUR, Bruno. Jamais fomos modernos: ensaio de antropologia simétrica. Trad: Carlos lrineu Costa. Rio de Janeiro: Ed. 34, 1994.

LAUSBERG, Heinrich. Elementos de retórica literária. 5 ed. Trad: R. M. Rosado Fernandes. Lisboa: Fundação Calouste Gulbenkian, 2004.

LIMA, Luiz Costa. Sob a face de um bruxo. In: Revista Eletrônica de Estudos Literários, Vitória, s. 1. a. 5. n. 5. p. 01- 73, 2009. 
MAINGUENEAU, Dominique. Discurso Literário. Trad: Adail Sobral. São Paulo: Contexto, 2006.

MELLO, Maria Elizabeth Chaves de. Sílvio Romero VS. Machado de Assis: crítica literária VS. Literatura crítica. In: Revista da apnpoll, Florianópolis, v. 1, n. 24, p. 178197, 2008.

MORAES, Eugênio Vinci de. A literatura como traição: os versos de Dante em "o Alienista". In: Machado de Assis em linha, Rio de Janeiro, v.6, n.11, p. 39-61, junho, 2013.

MOSCA, Lineide do Lago Salvador. Velhas e novas retóricas: convergências e desdobramentos. In: MOSCA, Lineide do Lago Salvador. (org.) Retóricas de Ontem e de Hoje. 3 ed. São Paulo: Humanitas, 2004.

POCOCK, John. Conceitos e discursos: uma diferença cultural? Comentário sobre o paper de Melvin Richter. In: JÚNIOR, João Feres. e JASMIN, Marcelo Gantus. História dos conceitos: debates e perspectivas. Rio de Janeiro: EdPUC-RIO: Edições Loyola: IUPERJ, 2006.

Linguagens do Ideário Político. São Paulo: EDUSP, 2003.

ROMUALDO, Jonas de Araújo. Ethos e discurso científico. In: MOTTA, Ana Raquel e SALGADO, Luciana. (orgs.). Ethos Discursivo. São Paulo: Contexto, 2008.

SKINNER, Quentin. “Quentin Skinner”. In: PALLARES-BURKE, Maria Lúcia Garcia. As Muitas Faces da História. São Paulo: UNESP, 2000.

SKINNER, Quentin. Visões da Política. Lisboa: DIFEL, 2005.

SOUZA, Roberto Acízelo de. A retórica no Brasil do século XIX: dos anos de glória à perdição. In: Variações sobre o mesmo tema: ensaios de crítica, história e teoria literárias. Chapecó, SC: Argos, p. 125-148. 2015.

SOUZA, Roberto Acízelo de. O império da eloqüência: retórica e poética do Brasil oitocentista. Rio de Janeiro: EdUerj, 1999.

VENTURA, Roberto. Estilo tropical: história cultural e polêmicas literárias no Brasil, 1870-1914. São Paulo: Cia das Letras, 1991.

WELLBERY, David E. Neo-retórica e desconstrução. Rio de Janeiro: EdUerj, 1998.

WITTGENSTEIN, Ludwig. Investigações Filosóficas. 6 ed. Trad. Emmanuel Carneiro Leão. Petrópolis. Vozes, 2009. 